\title{
Dynamic Modelling of Microalgae Cultivation Process in High Rate Algal
}

\section{Wastewater Pond}

\author{
Muhammadu Bello ${ }^{\mathrm{a}}$, Panneerselvam Ranganathan ${ }^{* \mathrm{~b}}$, Feargal Brennan ${ }^{\mathrm{a}}$ \\ ${ }^{a}$ Energy and Power Division, School of Energy, Environmental and Agrifood, Cranfield \\ University, Cranfield, MK43 0AL, United Kingdom. \\ ${ }^{\mathrm{b}}$ Process Engineering and Environmental Technology Division, CSIR-National Institute for \\ Interdisciplinary Science and Technology, Trivandrum-695019, India
}

\section{ABSTRACT}

In this work, a comprehensive dynamic mathematical modelling to simulate the production of microalgae in a High Rate Algal Pond (HRAP) is attempted. A synergetic algal-bacterial system comprising various interrelated biological and chemical system processes is presented. The dynamic behaviour of HRAP system is studied by solving mass balance equations of different components which account light intensity and gas-liquid mass transfer. The model predictions are compared with the previously reported studies in the literature. The influence of kinetic and operating parameters, including the supply of $\mathrm{CO}_{2}$, the maximum growth rate, pond depth and dilution rates, on the pond performance are evaluated. The sensitivity analysis of important process parameters is also discussed in this study. The developed model, as a tool, can be used to assess the factors that affect the pond performance criteria, including algal productivity and the dynamics of nutrient requirements.

Keywords: HRAP; Microalgae; Mathematical modelling; Wastewater treatment.

\footnotetext{
*Corresponding author. Tel: +91(0) 471 2515264; Email: panneerselvamr@niist.res.in.
} 


\section{Introduction}

High Rate Algal Ponds (HRAPs) for the treatment of wastewater obtained from municipal, industrial and agricultural sources are a potential technology to be used in cultivating algal biomass, because there is a growing interest in the development of effective and efficient wastewater treatment methods for domestic and industrial wastes with the concurrent need for alternative sources of energy and water. HRAPs are preferred among stabilization ponds because of its simplicity and economy [1]. HRAPs can serve as a potential nutrient provider for cultivating algae, in addition to wastewater treatment, with the possibility of reducing the cost of sustainable commercial production of biofuels from microalgae. The key characteristic feature of HRAPs is the symbiotic relationship between the photoautotrophic algae and the heterotrophic bacteria. Microalgal growth generates oxygen in the pond systems and thus facilitates dissolved oxygen concentration which in turn is required by aerobic bacteria for both oxidation and nitrification processes. Microalgae also consumes $\mathrm{CO}_{2}$ produced by the bacteria during the mineralization of pollutants. Integrating wastewater treatment with algal biomass production has the potential to reduce oxygen cost, mitigates $\mathrm{CO}_{2}$, and enhances nutrient assimilation and stripping processes. These processes stabilize wastes, facilitate the sedimentation process, and promote constructively algal growth coupled with driving the aerobic wastewater treatment synergistically [2]. Thus, the use of algalbacterium consortia has the potential to increase the economic feasibility and effectiveness of microalgae biomass production. Despite numerous benefits, the lack of knowledge on the design and operational parameters coupled with the management of microalgae-based processes has limited their widespread implementation. This is because of various complex physicochemical and biological processes that determine the efficiency of the pond characterization and the performance in HRAPs. These processes are: nutrient requirements for algae growth, dissolved oxygen that induces bacterial growth and biochemical oxidation 
of organic matters; $\mathrm{pH}$ that controls the rate of distinctive biochemical process; a temperature that controls the rate of biochemical reactions and transformations; light input for photosynthesis and hydraulic behaviour that govern the process of mixing in the pond [3]. To understand the process holistically and improve the efficiency of HRAPs from the standpoint of hydrodynamics through chemical and biological interactions, several studies using modelling approach have been attempted in the literature.

Buhr and Miller [4] have described a process modelling of biochemical interaction and symbiotic relationship of photosynthetic microalgae, and heterotrophic bacteria, and validated the HRAP process experimentally. The hydrodynamics of the system was considered as a series of continuous stirred tank reactors (CSTR) units with recirculation. The growth of both algae and microorganism was described by Monod kinetics. However, the effects of algal respiration and gaseous transformations in the pond are not being considered. Fallowfield et al. [5] have studied the validation of algal pond models to estimate net productivity, oxygen evolution and wastewater treatment capacity. Jupsin et al. [6] have presented a mathematical model of HRAP based on River Water Quality Model (RWQM) that was capable of simulating HRAP's operating cycles considering sediment oxygen demand. Grobbelaar et al. [7] have developed algal productivity models in terms of temperature and incident light. Recently, Yang [8] has extended the mathematical models developed by Buhr and Miller [4] to estimate the effect of $\mathrm{pH}$, dissolved oxygen and substrate concentrations on $\mathrm{CO}_{2}$ supply and utilization. He has considered the growth kinetics, thermodynamics and gas mass transfer, and the absorption of gases such as oxygen and ammonium.

The objective of the present study is to develop a dynamic model for microalgae production in HRAP under different operational conditions. The present model involves the prediction of biomass concentration, dissolved oxygen, total inorganic carbon and total inorganic nitrogen 
concentrations. The model also considers the effects of sparging $\mathrm{CO}_{2}$ with congruent sensitivity analysis of some other important parameters. The modelling methods used in this study are mostly drawn from the previous work of Buhr and Miller [4] and Yang [8]. However, there are some differences between this work and the previous literature work [4, 8] to build the present model in a simple way. These differences are following. $\mathrm{pH}$ limitation in the presented model is considered as the method described by James et al. [9]. This method involves the functional form of the relation between $\mathrm{pH}$ and dissolved $\mathrm{CO}_{2}$ derived from chemical equilibrium theory. $\mathrm{CO}_{2}$ mass transfer coefficient, $k_{l g, \mathrm{CO}_{2}}$ is calculated as based on the oxygen mass coefficient, $k_{l g, O_{2}}$ which is considered as a constant value in this work; Yang [8] used gPROMS as process modelling software to solve model equations, whereas, in this work model equations are solved using Matlab tool. The developed model as a tool can be employed to determine the pond performance criteria, including maximum algal productivity and nutrient requirements. Using prediction model, the effect of kinetic and operating parameters, such as supply of $\mathrm{CO}_{2}$, the maximum growth rate, pond depth and dilution rate, on the pond performance is presented. The sensitivity analysis of some important process parameters is also discussed in this study.

\section{HRAP model development}

The schematic algal pond is represented as shown in Figure 1 to depict the synergetic algalbacterial system comprising various interrelated biological and chemical processes. Wastewater can be described as a mixture of dissolved oxygen, dissolved inorganic nutrient concentrations and biological oxygen demand (BOD). $\mathrm{pH}$ of wastewater is an influential parameter that governs the biochemical transformation and substance balance in the reactor. The HRAP model also considers gaseous $\mathrm{CO}_{2}$ as a carbonaceous source. The assumptions considered in developing the models in this study are: (i) the pond is modelled as completely 
stirred tank reactors (CSTR); (ii) algal specific growth rate is a function of light intensity, total dissolved $\mathrm{CO}_{2}$ and total inorganic nitrogen; (iii) exchange of $\mathrm{O}_{2}$ and $\mathrm{CO}_{2}$ between the pond and the atmosphere is not included; (iv) evaporative losses are not considered due to lower water loss. It is noted in the literature that other nutrients such as phosphorus and micronutrient are not considered to be the limiting factor because these compounds are usually highly available in wastewater $[8,10]$. Thus, in the present study, this effect has not been explicitly considered with the assumption that the metabolism of the of the microbial consortium are not limited or inhibited by these compounds. Also, the ammonia volatilization and the removal of phosphorus by chemical precipitation occurring due to high $\mathrm{pH}$ (9-10) and temperature are not considered in the present study.

The model that describes the growth of photosynthetic microalgae in HRAP is a set of nonlinear differential equations derived from mass balance equations for both liquid and gaseous species transformations.

The average light intensity in the pond can be expressed in terms of concentration and depth of the pond $(z)$ at a particular time using the Beer-Lambert's law as [8]

$\mathrm{I}_{\mathrm{a}}=\frac{1}{z} \int_{0}^{\mathrm{Z}} \mathrm{I}_{0} \exp \left(-\mathrm{K}_{\mathrm{e}} \mathrm{z}\right) \mathrm{dz}$

where $z$ is the depth of the pond, $K_{\mathrm{e}}$ is the extinction coefficient related to the algal concentration, $X_{A}$ expressed as a simple linear relationship

118 Here $K_{e 1}$ and $K_{e 2}$ are constants and $I_{0}$ is the maximum surface light intensity during the photoperiod (5.00-19.00 hrs).

120 Combining Eqns. (1) and (2), the following relationship between the light intensity and the 121 distance from the surface is obtained as

$122 \quad I_{a}=\frac{\mathrm{I}_{0}}{Z} \exp \left(\frac{1-e^{-\left(K e_{1}+K e_{2} X a\right) Z}}{\left(K e_{1}+K e_{2} X a\right)}\right)$

123 The diurnal variation of the surface light intensity can be estimated as [11] 
$124 \quad \mathrm{I}_{0}(\mathrm{t})=\max \left(0, \mathrm{I}_{0} \pi\left(\sin \left(\frac{(t-5) 2 \pi}{24}\right)\right)\right)$

125 The light intensity factor for algae growth is thus modelled using Steele's function as [8]

$126 \quad f_{I}=\frac{\mathrm{I}_{a}}{\mathrm{I}_{s}} \exp \left(1-\frac{\mathrm{I}_{a}}{\mathrm{I}_{s}}\right)$

127 where $I_{S}$ is the saturation or optimum light intensity.

128 The mass balance of algae concentration in the effluent is expressed as [8]

$129 \quad \frac{\mathrm{dx}_{\mathrm{A}}}{\mathrm{dt}}=\frac{\mathrm{F}}{\mathrm{V}}\left(\mathrm{X}_{\mathrm{A}_{\mathrm{in}}}-\mathrm{X}_{\mathrm{A}}\right)+\mathrm{A}_{\mathrm{gr}}-r_{\mathrm{dA}}$

130 where $X_{A} F, V, A_{g r}$ and $r_{\mathrm{dA}}$ are the biomass concentrations per unit culture volume, the total 131 flow rate, the culture volume, the growth rate and the decay rate of algae, respectively.

132 Subscripts in is used to indicate the inlet concentration.

133 The growth rate of microalgae, $A_{g r}$ can be expressed as

$134 \quad \mathrm{~A}_{\mathrm{gr}}=\mu_{\mathrm{A}} \mathrm{X}_{\mathrm{A}}$

where $\mu_{A}$, and $X_{A}$ are the respective specific growth rate and mass concentration of algae.

The specific growth rate can be expressed in terms of light intensity $\left(f_{I}\right)$, maximum growth $\left(\mu_{M}\right)$ and nutrients (dissolved $\mathrm{CO}_{2}, \mathrm{CO}_{2 \mathrm{D}}$ and total inorganic nitrogen, $N_{T}$ ) in the form of

Monod-type function as [8]

139

$\mu_{\mathrm{A}}=\mu_{\mathrm{M}}\left(\frac{\mathrm{CO}_{2 \mathrm{D}}}{\mathrm{K}_{\mathrm{c}}+\mathrm{CO}_{2 \mathrm{D}}}\right)\left(\frac{\mathrm{N}_{\mathrm{T}}}{\mathrm{KN}_{\mathrm{A}}+\mathrm{N}_{\mathrm{T}}}\right) \mathrm{f}_{\mathrm{I}}$

where $\mu_{M}, K_{c}$ and $K N_{A}$ are constants. $\mathrm{CO}_{2 \mathrm{D}}$ can be obtained using $\mathrm{pH}$ dependence equation by an iteration method which is described at the end of this section.

The mass balance of total inorganic carbon can be written as

$\frac{d T I C}{d t}=\frac{\mathrm{F}}{V}\left(T_{I C} C_{i n}-\mathrm{TIC}\right)+\mu_{B} X_{B} Y_{\mathrm{BCO}_{2}}-\mu_{A} X_{A} Y_{\mathrm{ACO}_{2}}+f_{C O 2}-k_{l g, \mathrm{CO}_{2}} a\left(\mathrm{CO}_{2}^{*}-\mathrm{CO}_{2 \mathrm{D}}\right)$

where $T I C_{\text {in }}$ is the influent concentration of total inorganic carbon, $Y_{\mathrm{ACO}_{2}}$ and $Y_{\mathrm{BCO}_{2}}$ are the respective components mass yield, $f_{\mathrm{CO} 2}$ is the mass flux of $\mathrm{CO}_{2}, k_{l g, \mathrm{CO}_{2}}$ is the mass transfer 
146 coefficient and $\mathrm{CO}_{2}^{*}$ is the liquid phase $\mathrm{CO}_{2}$ concentration which is in equilibrium with the 147 gaseous $\mathrm{CO}_{2}$.

148 The total inorganic carbon concentration, $\mathrm{C}_{\mathrm{TIC}}$ includes not only the dissolved carbon dioxide 149 concentration $\left(\mathrm{CO}_{2 \mathrm{D}}\right)$, but also takes into account the carbonate concentration $\left(\mathrm{C}_{\mathrm{CO}_{3}^{2-}}\right)$ and 150 bicarbonate concentration $\left(\mathrm{C}_{\mathrm{CO}_{3}^{2-}}\right)$ species generated in the system in order to balance total 151 inorganic carbon.

152

$\mathrm{C}_{\mathrm{TIC}}=\mathrm{CO}_{2 \mathrm{D}}+\mathrm{C}_{\mathrm{HCO}_{3}^{-}}+\mathrm{C}_{\mathrm{CO}_{3}^{2-}}$

153 The concentration of carbonate ions entering into the TIC balance equation [10] is computed 154 by $\mathrm{pH}$ dependence and they can be calculated as

$155 \quad \mathrm{C}_{\mathrm{HCO}_{3}^{-}}=\frac{\mathrm{C}_{\mathrm{TIC}}}{1+\frac{\left[\mathrm{H}^{+}\right]}{\mathrm{k}_{1}}+\frac{\mathrm{k}_{2}}{\left[\mathrm{H}^{+}\right]}}$

$156 \quad \mathrm{C}_{\mathrm{CO}_{3}^{2-}}=\frac{\mathrm{C}_{\mathrm{TIC}}}{1+\frac{\left[\mathrm{H}^{+}\right]}{\mathrm{k}_{2}}+\frac{\left[\mathrm{H}^{+}\right]^{2}}{\mathrm{k}_{1} \mathrm{k}_{2}}}$

157 where $k_{1}$ and $k_{2}$ are the dissociations constant for $\mathrm{HCO}_{3}^{-}$and $\mathrm{CO}_{3}^{2-}$ respectively. Above equations (11-12) are derived using Eqn. (10) and the dissociation equations of $\mathrm{HCO}_{3}^{-}$and $159 \mathrm{CO}_{3}^{2-}$ which are discussed at the end of this section.

160 The equilibrium liquid phase concentration of $\mathrm{CO}_{2}$ can be written as

161

$\mathrm{CO}_{2}^{*}=\mathrm{H}_{\mathrm{CO} 2} \mathrm{P}_{\mathrm{CO} 2}$

162 where $P_{\mathrm{CO} 2}$ is the partial pressure of saturated $\mathrm{CO}_{2}$ and $\mathrm{H}$ is the Henry's constant for $\mathrm{CO}_{2}$.

163 The mass transfer coefficient of $\mathrm{CO}_{2}$ in water is used as [12]

$164 k_{l g, \mathrm{CO}_{2}}=k_{l g, \mathrm{O}_{2}} * \frac{D_{\mathrm{CO} 2}}{D_{\mathrm{O} 2}}$

165

where $k_{l g, O_{2}}$ is the mass transfer coefficient of $\mathrm{O}_{2}$ in water and

$D_{\mathrm{CO} 2}$ and $D_{\mathrm{O} 2}$ are the diffusion coefficient of $\mathrm{CO}_{2}$ and $\mathrm{O}_{2}$, respectively.

167

The mass balance of $N_{T}$ can be written as

168

$\frac{d N_{T}}{d t}=\frac{\mathrm{F}}{V}\left(N_{T_{\text {in }}}-N_{T}\right)-\mu_{B} X_{B} Y_{B N_{T}}-\mu_{A} X_{A} Y_{A N_{T}}$ 
where $N_{T_{\text {in }}}$ is the influent concentration of total inorganic nitrogen and $Y_{A N_{T}}$ and $Y_{B N_{T}}$ are

170 the respective components mass yield.

171 The decay rate of algae $\left(r_{\mathrm{dA}}\right)$ can be modelled in terms of dependent variable of algal 172 concentration $\left(X_{B}\right)$ as

$173 \quad r_{\mathrm{dA}}=\mathrm{k}_{\mathrm{dA}} \mathrm{X}_{A}$

174 where $k_{d A}$ is constant.

175 Similar to algal mass balance, bacterial concentration can be modelled as

$176 \quad \frac{\mathrm{dX}_{\mathrm{B}}}{\mathrm{dt}}=\frac{\mathrm{F}}{\mathrm{V}}\left(\mathrm{X}_{\mathrm{B} 0}-\mathrm{X}_{\mathrm{B}}\right)+\mathrm{r}_{\mathrm{gB}}-\mathrm{r}_{\mathrm{dB}}$

177 where $X_{B 0}$ is the influent concentration of bacteria.

178 The growth rate of bacteria, $r_{g B}$ can be calculated in the same manner as biomass concentration

$r_{\mathrm{gB}}=\mu_{\mathrm{B}} \mathrm{X}_{\mathrm{B}}$

181 where $\mu_{B}$ and $X_{\mathrm{B}}$ are the specific growth rate and mass concentration of bacteria. The nutrients, such as an organic substrate, oxygen and total inorganic nitrogen, are considered in this work. The specific growth rate of bacteria is described in the Monod-type equation can

184 be written as

$185 \quad \mu_{\mathrm{B}}=\mu_{B M}\left(\frac{\mathrm{S}}{\mathrm{K}_{\mathrm{S}}+\mathrm{S}}\right)\left(\frac{\mathrm{O}_{2}}{\mathrm{~K}_{\mathrm{O} 2}+\mathrm{O}_{2}}\right)\left(\frac{\mathrm{N}_{\mathrm{T}}}{\mathrm{K}_{\mathrm{NB}}+\mathrm{N}_{\mathrm{T}}}\right)$

where $\mu_{B M}, K_{S}, K_{O 2}$ and $K_{N B}$ are the half velocity constants and $S$ is the concentration of the substrate (BOD), respectively.

188 The substrate, $S$ balance can be attributed to the stoichiometric reaction of algal and bacterial 189 growth. The balance equation for substrate component can thus be written as

$190 \quad \frac{\mathrm{dS}}{\mathrm{dt}}=\frac{\mathrm{F}}{\mathrm{V}}\left(\mathrm{S}_{0}-\mathrm{S}\right)-\mu_{\mathrm{B}} \mathrm{X}_{\mathrm{B}} \mathrm{Y}_{\mathrm{B}}$

191 where $S_{0}$ and $Y_{B}$ are the influent concentration of substrate and mass yield of substrate (BOD) 192 consumed per unit mass of bacteria produced. 
The mass balance of $\mathrm{O}_{2}$ can be written as

194

$\frac{d O_{2}}{d t}=\frac{\mathrm{F}}{V}\left(O_{2_{\text {in }}}-O_{2_{\text {out }}}\right)-\mu_{B} X_{B} Y_{B O_{2}}+\mu_{A} X_{A} Y_{A O_{2}}+f_{O 2}-k_{l g, O_{2}} a\left(O_{2}^{*}-O_{2}\right)$

195 where $\mathrm{O}_{2}$ and $\mathrm{O}_{2}$ out are the respective influent and effluent concentrations of $\mathrm{O}_{2}$, $196 \mathrm{Y}_{\mathrm{AO}_{2}}$ and $Y_{\mathrm{BO}_{2}}$ are the respective components mass yield, $f_{\mathrm{O} 2}$ is the mass flux of $\mathrm{O}_{2}$, and 197 $k_{l g, O_{2}}$ and $O_{2}^{*}$ are the mass transfer coefficient and liquid phase $\mathrm{O}_{2}$ concentration that is in 198 equilibrium with the gas phase $\mathrm{O}_{2}$.

199 The equilibrium liquid phase concentration of $\mathrm{O}_{2}$ can be written as

200

$O_{2}^{*}=\mathrm{H}_{\mathrm{O} 2} \mathrm{P}_{\mathrm{O} 2}$

201 where $P$ is the partial pressure of $\mathrm{O}_{2}$ and $H$ is the Henry's constant for $\mathrm{O}_{2}$.

202 The decay rate $\left(r_{\mathrm{dB}}\right)$ depends on bacterial concentration $\left(X_{B}\right)$ and is modelled as

203

$\mathrm{r}_{\mathrm{dB}}=\mathrm{k}_{\mathrm{dB}} \mathrm{X}_{\mathrm{B}}$

204 where $k_{d B}$ is constant.

205 Now, $f_{g=\mathrm{CO} 2, \mathrm{O} 2}$ in Eqns. (9) and (21) can be estimated using the following relationship:

206

$\mathrm{f}_{\mathrm{g}}=\frac{1}{\mathrm{z}} \varepsilon \int \mathrm{k}_{\mathrm{lg}} \mathrm{a}\left(\mathrm{M}_{\mathrm{g}}^{*}-\mathrm{M}_{\mathrm{g}}\right) \mathrm{dz}$

207 Assuming the variation of dissolved $\mathrm{CO}_{2}$ and $\mathrm{O}_{2}$ along the height is negligible, $f_{g}$ can be 208 calculated as

$\mathrm{f}_{\mathrm{g}}=\varepsilon k_{l g} \mathrm{a}\left(\mathrm{M}_{\mathrm{g}}^{*}-\mathrm{M}_{\mathrm{g}}\right)$

209 where $M_{g}$ and $M_{g}^{*}$ are the liquid phase concentration and equilibrium liquid phase 210 concentration of gas species $\left(g=\mathrm{CO}_{2}\right.$ and $\left.\mathrm{O}_{2}\right), Z$ is the depth of the pond, $a$ is the interfacial 211 area $\left(a=6 / d_{b}\right)$ and $\varepsilon$ is the volume fraction of the gas hold up and can be determined as

$\varepsilon=\frac{\mathrm{n} \pi \mathrm{d}_{\mathrm{b}}^{3} \mathrm{f}}{6 \mathrm{U}_{\mathrm{gb}}}$

212 Here $d_{b}$ is the bubble diameter. The frequency of bubble formation, $f$ can be estimated from the number of each orifice as 
$f=\frac{6 Q_{0}}{\pi d_{0}^{3}}$

214 The gas volumetric flow rate, $Q_{o}$ is related to the number of orifices per unit area (n), total

215 surface area required for gas flow $\left(A_{g}\right)$ and total gas flow rate $(Q)$ as

$\mathrm{Q}_{0}=\frac{\mathrm{Q}}{\mathrm{nA}_{\mathrm{g}}}$

216 Furthermore, considering liquid velocity to be very small, bubble liquid slip velocity $217\left(U_{g b}\right)$ was approximated with the values of ascending velocity $\left(U_{g b}=\mathrm{u}_{\mathrm{rel}}\right)$ and thus, $218 U_{g b}$ can be determined as

$\mathrm{U}_{\mathrm{gb}}=\sqrt{\frac{4 \mathrm{~d}_{\mathrm{b}}}{3 \mathrm{C}_{\mathrm{D}}}}$

219 The drag force coefficient $\left(C_{D}\right)$ can be deduced using the following correlation [8]

$$
C_{D}=\left\{\begin{array}{ccc}
\frac{18.5}{\mathrm{Re}^{0.6}} & \text { for } & 1<R e<1000 \\
0.44 & \text { for } & \operatorname{Re} \geq 1000
\end{array}\right.
$$

220 Since the culturing mechanism of microalgae depends on the concentration of substrates, 221 such as carbon dioxide and nitrogen, $\mathrm{pH}$ influences the adsorption and desorption of nutrient 222 to enhance the bioavailability of organic matter. In this work, $\mathrm{pH}$ limitation in this model is 223 considered as the method described by James et al. [9]. The method involves the functional 224 form of the relation between $\mathrm{pH}$ and dissolved $\mathrm{CO}_{2}$ derived from chemical equilibrium theory. Gaseous $\mathrm{CO}_{2}$ contacts with $\mathrm{H}_{2} \mathrm{O}$ to become dissolved $\mathrm{CO}_{2}$, which in turn reacts with

$226 \mathrm{H}_{2} \mathrm{O}$ to form carbonic acid:

$227 \quad \mathrm{CO}_{2}+\mathrm{H}_{2} \mathrm{O} \leftrightarrow \mathrm{H}_{2} \mathrm{CO}_{3}$

228 The hydration constant of above equation is [9]

229

$k_{h}=\frac{\left[\mathrm{H}_{2} \mathrm{CO}_{3}\right]}{\mathrm{CO}_{2 \mathrm{D}}}=1.7 \times 10^{-3}$

230 where $\mathrm{CO}_{2 \mathrm{D}}$ is the concentration of dissolved $\mathrm{CO}_{2}$ and $\mathrm{H}_{2} \mathrm{CO}_{3}$ is a diprotic acid that can dissociate into two protons in a two-stage process:

232

$\mathrm{H}_{2} \mathrm{CO}_{3} \leftrightarrow \mathrm{HCO}_{3}^{-}+\mathrm{H}^{+}$ 
234 The dissociation constants for the above two stages [9] are given by :

$k_{1}=\frac{\left[\mathrm{H}^{+}\right]\left[\mathrm{HCO}_{3}^{-}\right]}{\left[\mathrm{H}_{2} \mathrm{CO}_{3}\right]}=4.45 \times 10^{-7}$

$236 \quad k_{2}=\frac{\left[\mathrm{H}^{+}\right]\left[\mathrm{CO}_{3}^{2-}\right]}{\left[\mathrm{HCO}_{3}^{-}\right]}=4.69 \times 10^{-11}$

237 with the assumption that carbonic acid is a weak monoprotic acid, $\left[\mathrm{CO}_{3}^{2-}\right]$ formed during the 238 second dissociation of $\left[\mathrm{HCO}_{3}^{-}\right]$is neglected, the following equation can be obtained 239 according to James et al. [9] as

$240 \quad k_{1}=\frac{\left[\mathrm{H}^{+}\right]\left(\left[\mathrm{H}^{+}\right]-\left[\mathrm{OH}^{-}\right]\right)}{k_{h} \mathrm{CO}_{2 \mathrm{D}}-\left[\mathrm{H}^{+}\right]+\left[\mathrm{OH}^{-}\right]}$

241 Using the hydration constant for water, $k_{\mathrm{w}}=\left[\mathrm{H}^{+}\right]\left[\mathrm{OH}^{-}\right]=1.008 \times 10^{-14}$, and using $\left[\mathrm{OH}^{-}\right]=$ $k_{\mathrm{w}} /\left[\mathrm{H}^{+}\right]$, the simplified expression of $k_{1}$ in terms of $\left[\mathrm{H}^{+}\right]$is

$\left[H^{+}\right]^{3}+k_{1}\left[H^{+}\right]^{2}-\left(k_{1} k_{h} \mathrm{CO}_{2 \mathrm{D}}+k_{w}\right)\left[H^{+}\right]-k_{1} k_{w}=0$

244 In Eqn.(38), $k_{1} k_{\mathrm{w}}$ is negligible due to smaller value $\left(\sim O\left(10^{-21}\right)\right)$; so it can be reduced to a 245 quadratic equation

$246\left[H^{+}\right]^{2}+k_{1}\left[H^{+}\right]-k_{1} k_{h} \mathrm{CO}_{2 \mathrm{D}}+k_{1}=0$

247 The above quadratic equation can be solved numerically and approximated into a simple expression for $\mathrm{H}^{+}$as a function of $\left[\mathrm{CO}_{2}\right]$ and is given as

$\left[H^{+}\right]=\left(k_{w}+k_{1} k_{h} \mathrm{CO}_{2 \mathrm{D}}\right)^{0.5}$

In this work, the iterative method is used to calculate $\mathrm{CO}_{2 \mathrm{D}}$ which is further used to find $\mathrm{pH}$ using Eq.(40). At the first iteration, using the initial $\mathrm{pH}$ (assumed 7.2) and initial total inorganic carbon concentration $\left(\mathrm{C}_{\mathrm{TIC}}\right)$, the carbonate ions are computed from Eqns. (11) and (12). The carbonate ions are further used to calculate $\mathrm{CO}_{2 \mathrm{D}}$ concentration from Eqn. (10). Using $\mathrm{CO}_{2 \mathrm{D}}$ concentration, the concentration of $\mathrm{H}$ ion is calculated from Eq. (40) for the next iteration. The iterations are running until the difference between the previous iteration and the current iteration for $\mathrm{CO}_{2 \mathrm{D}}$ is negligible. The iteration method used in this work can be 
improved by a solving system of algebraic equations of all ionic species which describe chemical equilibrium of $\mathrm{CO}_{2}-\mathrm{NH}_{3}-\mathrm{H}_{2} \mathrm{O}$ system. Since this thermodynamic model involves a multi-solute system of $\mathrm{CO}_{2}-\mathrm{NH}_{3}-\mathrm{H}_{2} \mathrm{O}$ which requires a substantial work to couple with biological models, the improvement in the present model for $\mathrm{pH}$ calculation will be addressed in future.

\section{Results and Discussion}

\subsection{Model validation}

Simulations were conducted using Matlab with ODE23s function. Since the detailed experimental results of co-culture of bacteria and algae for high-rate wastewater treatment ponds are hard to find in the literature, the validation of the present model was performed to simulate microalgae cultivation in wastewater using two different literature studies. First one is the model development for algal-bacteria interaction in the open system and the second one is an algae cultivation in a synthetic medium simulating treated urban wastewater (secondary effluent) in raceways ponds. The experimental and simulation data of Bai [13] was considered for the algae-bacteria interaction in the open system. Bai studied the contribution of bacteria on the microalgae cultivation in open algal systems by accounting carbon cycling and further, developed an expanded algae-bacteria conceptual model which considers the comprehensive carbon and nutrient fluxes in open algal systems, considering the activity of heterotrophic bacteria. A simulation was performed for this specific operating condition described by him to validate the present model. Figure 2a shows the comparison plot of algae concentration between the present model and experimental findings of Bai [13] along with the simulation result reported by him. It is seen that the predicted algae concentration profile of the present model shows the similar trend with a small deviation shown by the experimental observation. However, the trend closely matches with the author's modelling 
work. Also, it can be seen from the figure that the simulated profile shows a wavelike trend which indicates that the model can be able to reproduce both algae growth and inactivation cycles occurring during daytime and at night, respectively. In another validation study, the experimental and simulation data of Solimeno et al. [10] was considered for algae cultivation using urban wastewater in open raceway ponds. They carried out batch cultivation of algae in an open pond with the volume of 500L. The authors used a synthetic medium which is similar to the mineral composition of wastewater. They had also developed a mechanistic model to simulate microalgae growth, considering carbon-limited growth, transfer of gases, photorespiration and photosynthesis kinetics. Figure $2 \mathrm{~b}$ shows the comparison plot of algae concentration between the present model and experimental findings of Solimeno et al. [10] along with their simulation result. It is found that the predicted algae concentration profile of the present model matches with the experimental observation reported by Solimeno et al. [10]. It is also worth to mention that the present model shows a better prediction compared to the author's modelling work.

\subsection{Base case simulation}

Base case simulation of algae-bacteria co-culture for high-rate waste water treatments ponds was conducted to present the dynamics and the performance of the HRAP system. The model parameters used in a base case simulation are presented in Table 1. The design and operating parameters adopted for the simulation are presented in Table 2. Main operating conditions used for the simulation scenarios were constant feed flow rate of $50 \mathrm{~m}^{3} /$ day with the dilution rates varies between 0 and 1 day $^{-1}$, considering the typical HRAPs pond depth of $0.1-0.4 \mathrm{~m}$ based on the literature $[1,8,14,15]$. Figure 3 presents the results of the modelling of the algae biomass growth rate and $\mathrm{pH}$ variation during $24 \mathrm{hrs}$ period along with the previously reported results by Yang [8] for testing of the present models. The process conditions used in 
this case are: the pond depth of $0.4 \mathrm{~m}$, the dilution rate of $0.35 \mathrm{day}^{-1}$, the maximum specific growth rate of $0.693 \mathrm{day}^{-1}$ and the $\mathrm{CO}_{2}$ flow rate of $10 \mathrm{~m}^{3} / \mathrm{hr}$. It can be seen from the figure that the model predicted profiles of algae concentration and $\mathrm{pH}$ have a similar trend with the previous work of Yang [8]. However, there was a deviation in $\mathrm{pH}$ profile between the prediction of the present model prediction and that of Yang [8]. This may be due to the different methods for $\mathrm{pH}$ calculation. Also, it is found from Figure 3a that during the photoperiod (5.00-19.00hrs) the growth of algae biomass increases whereas it decreases during the absence of photo light period. It is noteworthy to mention that algal biomass concentration profile follows the $\mathrm{pH}$ profile. This implies that the production of algal biomass in HRAPs is based on the influence of $\mathrm{pH}$ stemming from the utilisation of $\mathrm{CO}_{2}$ as a major carbonaceous source. There is a shift in carbonate chemical equilibrium if $\mathrm{CO}_{2}$ consumed by algae in the pond, which will automatically increase $\mathrm{pH}$ as well as the algal biomass production. Therefore, the growth of algae implies the $\mathrm{pH}$ control by means of $\mathrm{CO}_{2}$ addition in the pond [16]. However, the change in $\mathrm{CO}_{2}$ concentration in the pond induces the change in $\mathrm{pH}$, which is substantially affected by its solubility [17]. Thus, the addition of $\mathrm{CO}_{2}$ will increase the availability of carbon for algal growth with congruent improvement in the removal efficiency of nutrient [18].

Figures $4(\mathrm{a}-\mathrm{c})$ exhibit the diurnal behaviour of dissolved oxygen, total inorganic carbon and total inorganic nitrogen concentrations in the pond. It is found that the cyclic trend of dissolved oxygen matches with the report of Yang [8]. During the day, when the external irradiance increases, it is shown that the dissolved oxygen increases and reaches to $6.5 \mathrm{~g} / \mathrm{m}^{3}$ at 19:00hr and then sharply decreases. Similarly, it is shown that the concentration of total inorganic carbon decreases at the same period when the concentration of oxygen increases in the pond which is a clear indication of photosynthetic growth. The dissolved oxygen concentration depends on the organic loads and the type of biomass presents in the HRAP. In 
fact, $\mathrm{pH}$ and $\mathrm{DO}$ values were higher in the pond during the day due to photosynthetic activity present in the pond. Figure $4 \mathrm{c}$ shows a substantial decreasing trend of total inorganic nitrogen concentration in the pond during the dark period, whereas, in the photoperiod, the total inorganic nitrogen concentration still decreases towards to constant and then increases towards to a constant value in the dark period. The increase in total inorganic nitrogen concentration in the dark period that cannot be seen in the main Figure $4 \mathrm{c}$ because of scale is clearly shown in the inset of Figure 4c. Nitrogen is being consumed and reduced in the pond during the day as both the $\mathrm{pH}$ and algal biomass productivity increase. Also, the consortium of bacteria present in the system coupled with the loss of nitrogen to the atmosphere at the same time may induce the additional total inorganic nitrogen reduction. Besides bicarbonate equilibrium due to $\mathrm{CO}_{2}$ gas sparging, the $\mathrm{pH}$ is also influenced by the dynamic equilibrium exists between $\mathrm{NH}_{4}{ }^{+}$ions and $\mathrm{NH}_{3}$.

\subsection{Influence of $\mathrm{CO}_{2}$ sparging on algae concentration}

Figure 5 shows the predicted concentration profiles of algal biomass, $\mathrm{pH}$, dissolved oxygen, and dissolved carbon dioxide versus the time for the cases of both with and without $\mathrm{CO}_{2}$ inlet flow rate. The process conditions are: the pond depth of $0.4 \mathrm{~m}$, the dilution rate of $0.35 \mathrm{day}^{-1}$, and the maximum specific growth rate of $0.693 \mathrm{day}^{-1}$. It is obvious from Figure 5a that the amount of algae produced in the pond is low when $\mathrm{CO}_{2}$ is not sparging to the system. This behaviour agrees with the literature [10]. There is the concomitant production of oxygen and consumption of carbon dioxide and increasing $\mathrm{pH}$ concentration during the day.

\subsection{Parameter studies}

Simulations were conducted to evaluate the effect of some important parameters on the pond performance. The effects of pond depth, dilution rate, and biochemical oxygen demand on the pond performance were thus evaluated. These parameters are paramount to the maximization 
357 of algal biomass production and nutrient consumptions efficiency. Moreover, these parameters are interconnected to the biochemical system on the light penetration in the pond, gaseous mass transfer, microalgal growth rate and the extent of organic matter degradation in the pond $[8,10]$. Thus, understanding the trend of variation of algae biomass concentration with respect to the pond depth being a design variable and dilution rate being an operating variable is important for algal biomass production and optimization.

Figures $6(\mathrm{a}-\mathrm{c})$ show the effect of algal productivity as the pond depth varies from 0.1 to $0.4 \mathrm{~m}$, dilution rate varies from 0.1 to $0.4 \mathrm{day}^{-1}$ and BOD varies from 50 to $300 \mathrm{~g} / \mathrm{m}^{3}$. As shown in Figure 6a, the algal areal productivity decreases with the pond depth due to the reduction in the surface area and thus lowers the acquisition of atmospheric $\mathrm{CO}_{2}$. Similar trends are also reported in the literature $[8,10]$. The results reveal that the longer residence time and the lower concentration of microalgae in the pond may lead to the decline of algal productivity. However, Sutherland et al. [19] reported that the increasing pond depth increases the areal productivity, the nutrient removal efficiency as well as increased photosynthetic activity. Nevertheless, increasing pond depth may promote $\mathrm{CO}_{2}$ fixation and removal efficiency, but it may not promote high algal yield necessarily. Figure $6 \mathrm{~b}$ represents the plot of dilution rates versus algal areal productivity. Selecting the ranges of dilution rate with unique growth rate helps in achieving a steady state that can be used to optimize biomass productivity. Based on this point, the continuous outdoor culture is composed of cyclic variations in culture conditions that determine day and night biomass productivities. Simulations were performed considering an optical pond depth of $0.1 \mathrm{~m}$, maximum growth rate of $0.693 \mathrm{day}^{-1}$, initial biomass concentrations in the pond as $383 \mathrm{~g} / \mathrm{m}^{3}$ coupled with dilution rates of $0.1,0.2,0.25$ and $0.35 \mathrm{day}^{-1}[11,15]$. It is obtained that the areal productivity increases with dilution rates and the maximum dilution rate obtainable under the condition of $0.3 \mathrm{day}^{-1}$ which corresponds to the areal productivity of $3.98 \mathrm{kgcm}^{-2} \mathrm{day}^{-1}$. A slight variation 
in algal productivity is found when BOD increases from $50 \mathrm{~g} / \mathrm{m}^{3}$ to $400 \mathrm{~g} / \mathrm{m}^{3}$, which is shown in Figure 6c. This is an indication of the consumption of $\mathrm{CO}_{2}$ by algae that has been produced by bacteria in the pond. But algal productivity decreases after $400 \mathrm{~g} / \mathrm{m}^{3}$ due to the nitrogen starvation caused by the simultaneous growth of bacteria and $\mathrm{CO}_{2}$ consumption by the growth of algae [8].

\subsection{Sensitivity analysis}

Sensitivity analysis was conducted on the few parameters of the present model. For each parameter, three cases were performed to obtain distinctive profiles of microalgae concentration with keeping the rest of the parameters at same as base case condition. A variation of the parameters within the range of $\pm 10 \%$ was used for microalgae biomass concentration predictions.

Figure 7 presents the results of sensitivity analysis on algae concentration by varying the parameters of algal decay rates $\left(k_{d a}\right)$, the maximum specific growth rates $\left(\mu_{M}\right)$ and the saturation light intensity $\left(I_{S}\right)$ and the half saturations constant $\left(K_{C}\right)$ which are considered as most important predetermined constants of the model. It is found that the model seems to be insensitive to the nutrient determined half saturations constant for cell growth $\left(K_{C}\right)$. A similar finding has been revealed by Park and Li [17]. However, the model has a slightly higher influence on algae concentration by varying of algal decay rates $\left(k_{d a}\right)$, the maximum specific growth rates $\left(\mu_{M}\right)$ and the saturation light intensity factor $\left(I_{S}\right)$.

\section{Conclusion}

Dynamic characteristics of microalgae culture in HRAP were investigated through the development of a comprehensive mathematical modelling. A combined effect of light 
intensity, biological model, and gas-liquid mass transfer on the prediction of process parameters was studied in this study. Predictions of various components such as biomass productivity, $\mathrm{pH}$, dissolved oxygen, total inorganic carbon, and total inorganic nitrogen concentrations were reported. The effects of design and operating parameters on the biomass productivity were also investigated. The various conclusions that can be drawn from this study are as follows:

- The $\mathrm{pH}$ and biomass productivity obtained in this study are in accordance with the literature.

- The addition of $\mathrm{CO}_{2}$ regulates $\mathrm{pH}$, enhances the biomass productivity and thus, its concentration in the pond is critical, which must be available at a sufficient concentration to maintain a dynamic balance for algal-bacterial consortium.

- Oxygen production in the pond is mainly from photosynthesis process that is dependent on algal growth rate, light intensity, temperature and $\mathrm{pH}$. Its concentration is inversely related to the concentration of $\mathrm{CO}_{2}$.

- The effect of an increase in biomass productivity depends not only on light intensity but also on the imposed dilution rate and pond depth.

The present model can be used effectively for simulating various conditions and in further refinement of design and operating procedures for the HRAPs. This model will be useful for scale-up and optimization of microalgal biomass production process. 


\section{Acknowledgment}

427 Author (MB) gratefully acknowledges the financial support (PTDF/E/OSS/PHD/MB/407/11)

428

429

430

431

432

433

434

435

436

437

\section{References}

[1] R. Craggs, D. Sutherland, H. Campbell, Hectare-scale demonstration of high rate algal ponds for enhanced wastewater treatment and biofuel production, J.Appl.Phycol. 24 (2012) 329-337.

[2] W. Oswald, H. Gotaas, C. Golueke, W. Kellen, E. Gloyna, E. Hermann, Algae in Waste Treatment [with Discussion], Sewage Ind. Wastes 29 (1957) 437-457.

[3] L. Sah, D.P. Rousseau, C.M. Hooijmans, Numerical modelling of waste stabilization ponds: where do we stand?, Water Air \& Soil Pollut. 223 (2012) 3155-3171.

[4] H. O. Buhr, S.B. Miller, A dynamic model of the high-rate algal-bacterial wastewater treatment pond, Water Res.17 (1983) 29-37.

[5] H. Fallowfield, F. Mesple, N. Martin, C. Casellas, J. Bontoux, Validation of computer models for high rate algal pond operation for wastewater treatment using data from Mediterranean and Scottish pilot scale systems: implications for management in coastal regions, Water Sci \& Technol. 25 (1992) 215-224.

[6] H. Jupsin, E. Praet, J.L. Vasel, Dynamic mathematical model of high rate algal ponds (HRAP), Water Sci. Technol. 48 (2003) 197-204.

[7] J.U. Grobbelaar, C.J. Soeder, E. Stengel, Modelling algal productivity in large outdoor cultures and waste treatment systems, Biomass 21 (1990) 297-314. 
451 [8] A. Yang, Modelling and evaluation of $\mathrm{CO}_{2}$ supply and utilization in algal ponds, Ind. Eng. $452 \quad$ Chem. Res. 50 (2011) 11181-11192.

453 [9] S. C. James, V.Janardhanam, D. T. Hanson, Simulating pH effects in an algal-growth 454 hydrodynamics model, J. Phycol. 49 (2013) 608-615.

455

456

457

458

459

460

461

462

463

464

465

466

467

468

469

470

471

472

473

[10] A. Solimeno, R. Samsó, E. Uggetti, B. Sialve, J.P. Steyer, A. Gabarró, J. García, New mechanistic model to simulate microalgae growth, Algal Res. (2015) 350-358.

[11] J. A. Gomez, K. Höffner, P. I. Barton, From sugars to biodiesel using microalgae and yeast. Green Chem. 18 (2016) 461-475.

[12] X. Bai, P. Lant, S. Pratt, The Contribution of Bacteria to Algal Growth by Carbon Cycling, Biotechnol. Bioeng. 112 (2015) 688-695.

[13] X.Bai, Enhancing algal biomass and biofuels recovery from open culture systems, $\mathrm{PhD}$ Thesis 2015, The University of Queensland, Australia.

[14] R. Craggs, J. Park, D. Sutherland, S. Heubeck, Economic construction and operation of hectare-scale wastewater treatment enhanced pond systems, J. App. Phyco. 27 (2015) 1913-1922.

[15] P. Kenny, K. J. Flynn, In silico optimization for production of biomass and biofuel feedstocks from microalgae, J. App. Phyco. 27 (2015) 33-48.

[16] G.A. Ifrim,M. Titica, G. Cogne, L. Boillereaux, J. Legrand,S. Caraman, Dynamic pH model for autotrophic growth of microalgae in photobioreactor: A tool for monitoring and control purposes, AIChE.J. 60 (2014) 585-599.

[17] S. Park, Y. Li, Integration of biological kinetics and computational fluid dynamics to model the growth of Nannochloropsis salina in an open channel raceway, Biotechno. Bioeng. 112(2015) 923-933. 
480

481

482

483

484

485

486

487

488

489

490

491

492

493

494

495 496

497

498 5

[18] Z. Arbib, J. Ruiz, P. Álvarez-Díaz, C. Garrido-Pérez, J. Barragan, J. A. Perales, Effect of $\mathrm{pH}$ control by means of flue gas addition on three different photo-bioreactors treating urban wastewater in long-term operation, Ecol. Eng. 57(2013) 226-235.

[19] D. L. Sutherland, M. H. Turnbull, R. J. Craggs, Increased pond depth improves algal productivity and nutrient removal in wastewater treatment high rate algal ponds, Water Res. 53 (2014) 271-281.

(1)

(1)

2

3

84

(1)

86

87

88

89

0

4

92

93

4 


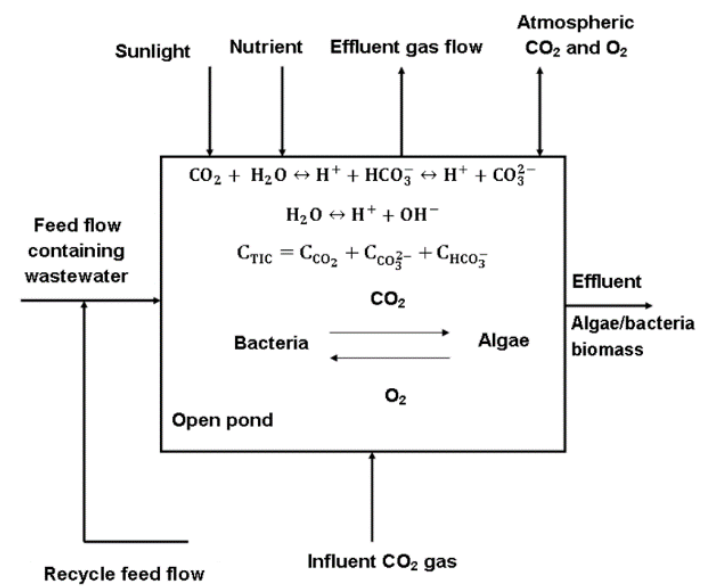

501 Figure 1: Schematic diagram of the algal pond system with recirculation [8]
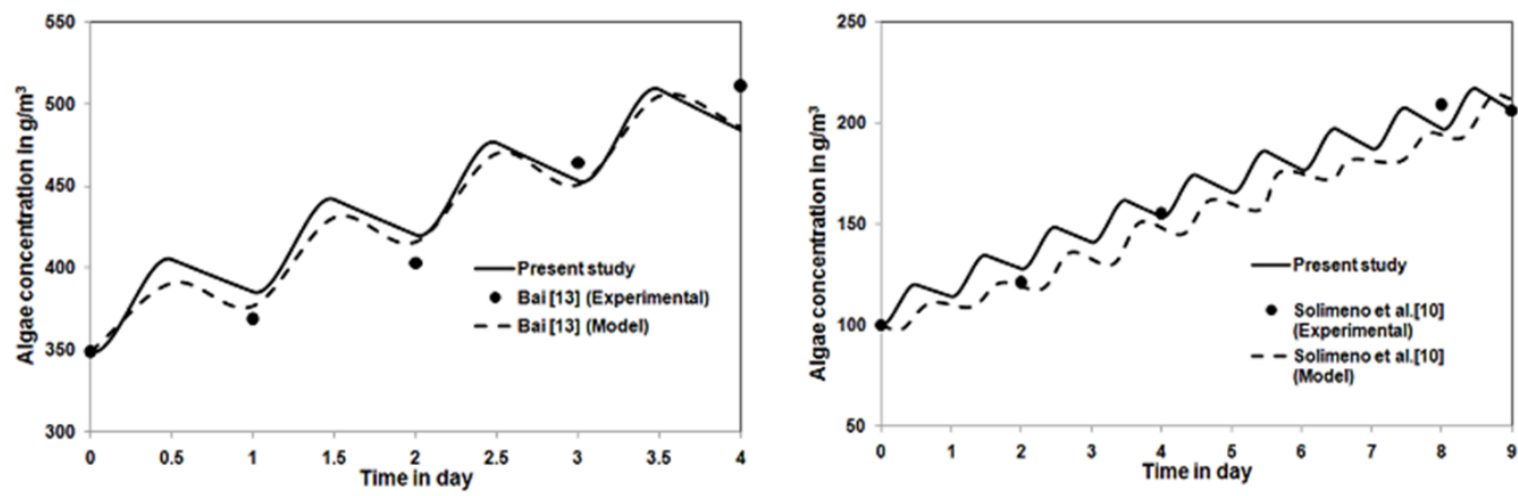

502

503

Figure 2: A comparison plot of algae concentration between this work and the literature [10, 504 13]
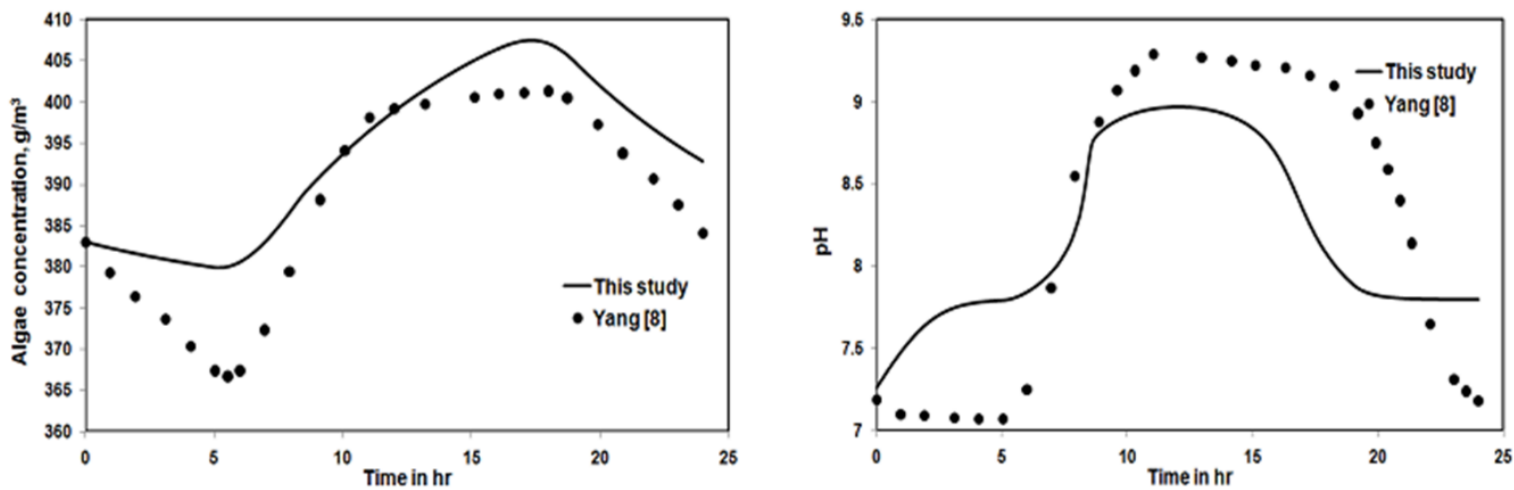

Figure 3: (a) Algal concentration and (b) $\mathrm{pH}$ validations in HRAP along with 24hrs period 

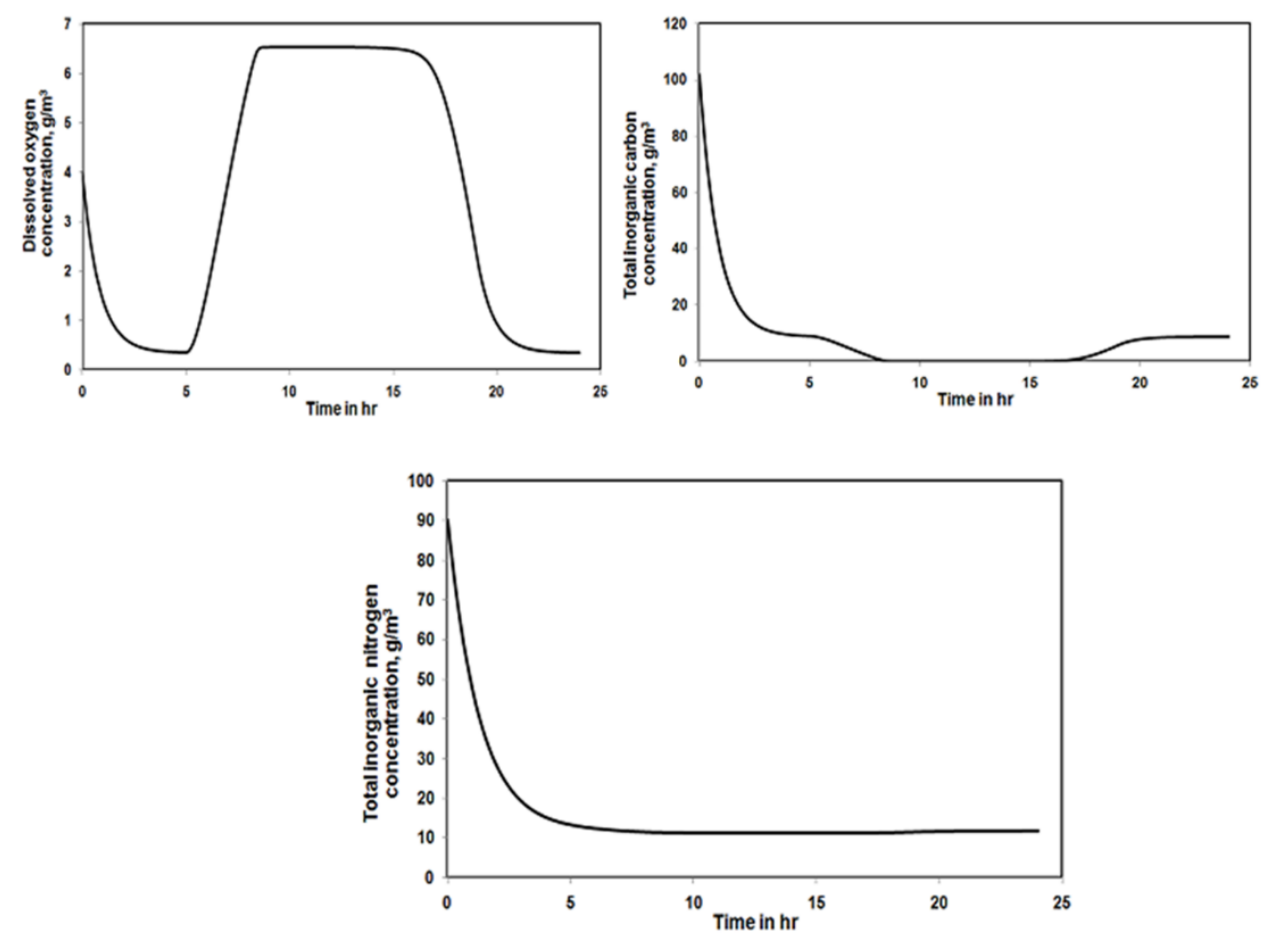

511 Figure 4: (a) Dissolved oxygen (b) Total inorganic carbon and (c) Total inorganic nitrogen 512 profiles in HRAP along the $24 \mathrm{hrs}$ period
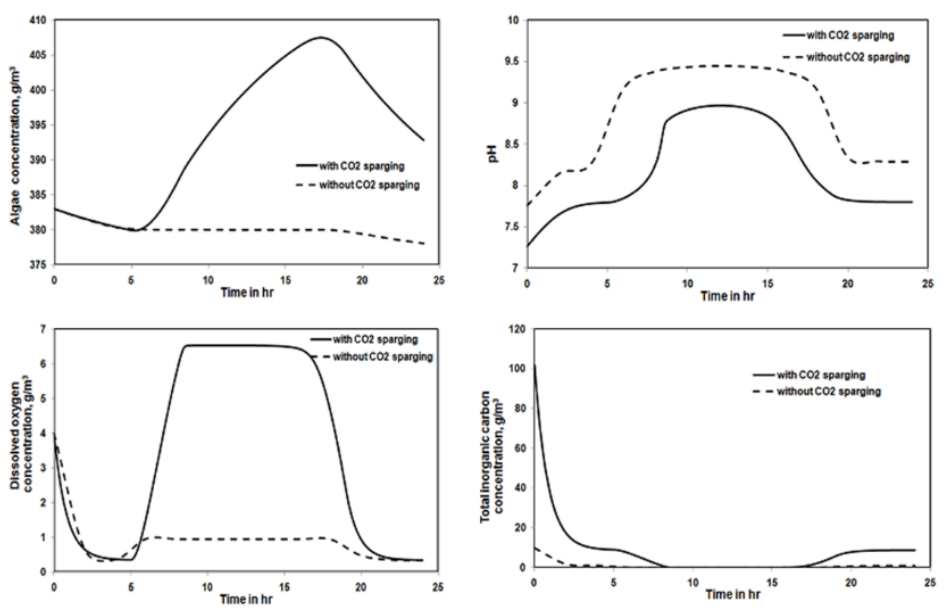

514 Figure 5: (a) Algal biomass concentration, (b) $\mathrm{pH}$, (c) Dissolved oxygen (DO) and (d) total 515 inorganic carbon profiles along the $24 \mathrm{hrs}$ period for the case of without $\mathrm{CO}_{2}$ sparging. 
(a)

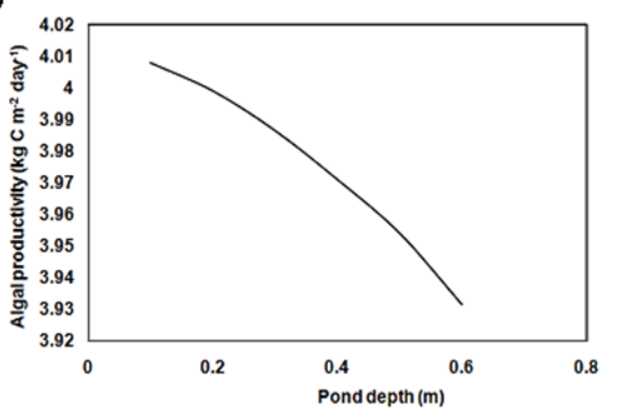

(b)

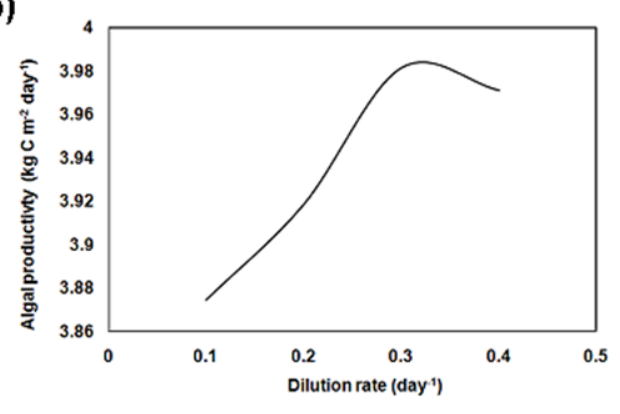

516

517 Figure 6: Plots of (a) pond depth, (b) dilution rate and (c) BOD versus areal productivity of 518 algae biomass

(c)

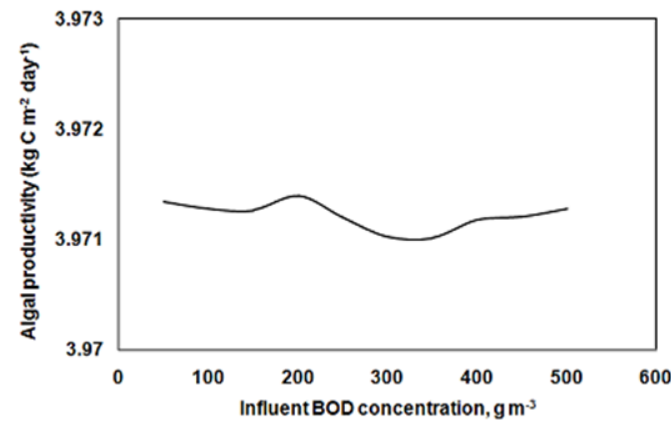

519

(a)

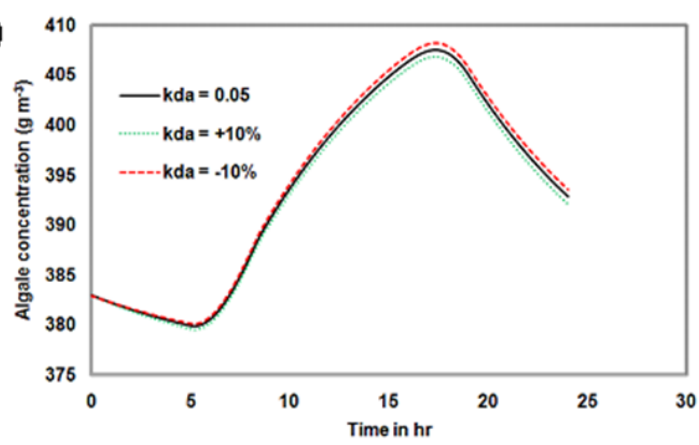

(c)

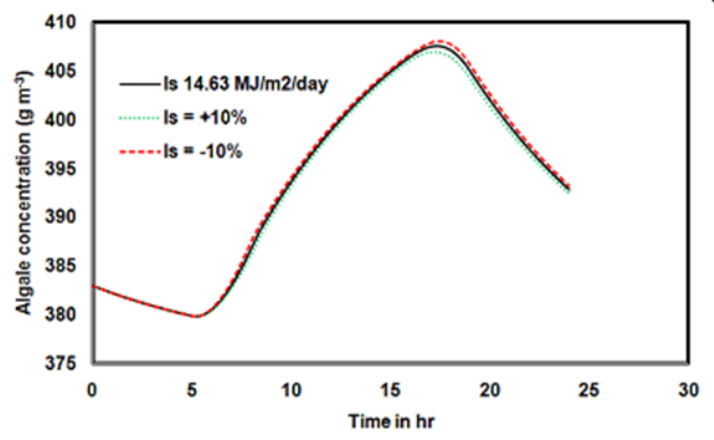

(b)

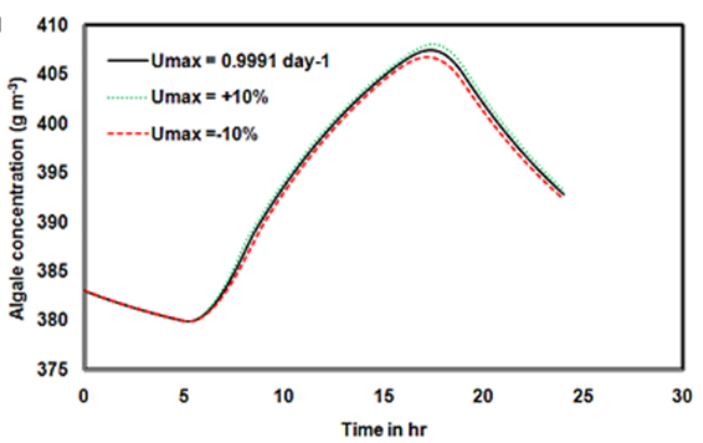

(d)

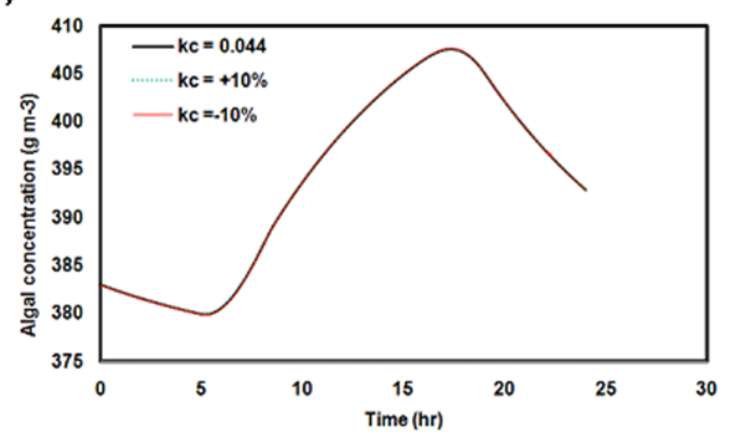

523 Figure 7: Sensitivity analysis of (a) decay rate (b) maximum specific growth rate (c) 524 saturation light intensity (d) nutrient half saturation constant on algal biomass concentration 


\section{List of Tables}

526 Table 1: Values of model parameters employed in simulation

527 Table 2: Design and Operating Parameters employed in the mathematical model

528

529

530

531

532

533

534

535

536

537

538

539

540

541

542

543

544

545

546

547

548

549

550

551 
Table 1

\begin{tabular}{|c|c|c|c|c|}
\hline Parameter description & Symbol & Value & Unit & Reference \\
\hline $\begin{array}{c}\text { Maximum specific rate of } \\
\text { algae }\end{array}$ & $\mu_{\mathrm{M}}$ & 0.9991 & days $^{-1}$ & Yang [8] \\
\hline $\begin{array}{c}\text { Maximum specific rate of } \\
\text { bacteria }\end{array}$ & $\mu_{B M}$ & 5.0432 & days $^{-1}$ & Yang [8] \\
\hline $\begin{array}{l}\text { Henrys constant (Carbon } \\
\text { dioxide) }\end{array}$ & $\mathrm{K}_{\mathrm{H}(\mathrm{CO} 2)}$ & 0.90315 & $\mathrm{~g} /\left(\mathrm{m}^{3} \mathrm{~atm}\right)$ & Yang [12] \\
\hline Henrys constant (Oxygen) & $\mathrm{K}_{H(O 2)}$ & 0.04416 & $\mathrm{~g} /\left(\mathrm{m}^{3} \mathrm{~atm}\right)$ & Yang [12] \\
\hline $\begin{array}{l}\text { Dissociation constants for } \\
\text { carbonic acids system }\end{array}$ & $\mathrm{K}_{\mathrm{A}}$ & $1.76 \mathrm{e}-05$ & & Ifrim et al. [15] \\
\hline $\begin{array}{l}\text { Dissociation constants for } \\
\text { carbonic acids system }\end{array}$ & $\mathrm{K}_{1 \mathrm{C}}$ & $4.38 \mathrm{e}-07$ & & Ifrim et al. [15] \\
\hline $\begin{array}{l}\text { Dissociation constants for } \\
\text { carbonic acids system }\end{array}$ & $K_{2 C}$ & $4.65 \mathrm{e}-11$ & & Ifrim et al. [15] \\
\hline $\begin{array}{l}\text { Yield conversion } \\
\text { coefficient (BOD) } \\
\text { consumed }\end{array}$ & $Y_{B}$ & 2.5 & $\begin{array}{c}\text { g BOD consumed } \\
\text { ( } g \text { bacteria mass produced })\end{array}$ & Yang [8] \\
\hline $\begin{array}{c}\text { Yield conversion } \\
\text { coefficient of } \mathrm{CO}_{2} \\
\text { consumed per unit mass of } \\
\text { algae produced }\end{array}$ & $Y_{A, C O_{2}}$ & 2.812 & $\begin{array}{c}\mathrm{g} \mathrm{CO}_{2} / \mathrm{g} \text { algal mass } \\
\text { produced }\end{array}$ & Park and $\mathrm{Li}[16]$ \\
\hline $\begin{array}{l}\text { Yield coefficient of } \\
\text { oxygen produced per unit } \\
\text { mass of algae produced }\end{array}$ & $Y_{A, O_{2}}$ & 1.587 & $\begin{array}{c}\mathrm{g} \mathrm{O}_{2} / \mathrm{g} \text { algal mass } \\
\text { produced }\end{array}$ & Park and Li [16] \\
\hline $\begin{array}{c}\text { Yield conversion } \\
\text { coefficient of Nitrogen } \\
\text { consumed per unit mass of } \\
\text { algae produced }\end{array}$ & $Y_{A, N}$ & 0.091 & $\mathrm{~g} \mathrm{~N} / \mathrm{g}$ algal mass produced & Park and $\mathrm{Li}[16]$ \\
\hline $\begin{array}{l}\text { Yield conversion } \\
\text { coefficient of } \mathrm{CO}_{2}\end{array}$ & $Y_{B, C O_{2}}$ & 3.432 & $\begin{array}{c}\mathrm{g} \mathrm{CO} / \mathrm{g} \text { bacteria mass } \\
\text { produced }\end{array}$ & Park and $\mathrm{Li}[16]$ \\
\hline
\end{tabular}




\begin{tabular}{|c|c|c|c|c|}
\hline Parameter description & Symbol & Value & Unit & Reference \\
\hline \multicolumn{5}{|l|}{$\begin{array}{l}\text { produced per unit mass of } \\
\text { bacteria produced }\end{array}$} \\
\hline $\begin{array}{c}\text { Yield coefficient of } \mathrm{O}_{2} \\
\text { consumed per unit mass of } \\
\text { bacteria produced }\end{array}$ & $Y_{B, O_{2}}$ & 2.496 & $\begin{array}{c}\mathrm{g} \mathrm{O}_{2} / \mathrm{g} \text { bacteria mass } \\
\text { produced }\end{array}$ & Park and $\mathrm{Li}[16]$ \\
\hline $\begin{array}{c}\text { Yield coefficient of } \\
\text { Nitrogen consumed per } \\
\text { unit mass of bacteria } \\
\text { produced }\end{array}$ & $Y_{B, N}$ & 0.1239 & $\begin{array}{c}\mathrm{g} \mathrm{N} / \mathrm{g} \text { bacteria mass } \\
\text { produced }\end{array}$ & \\
\hline Algae decay coefficient & $k_{d a}$ & 0.05 & days $^{-1}$ & Yang [8] \\
\hline Bacteria decay coefficient & $K_{d b}$ & 0.10 & days $^{-1}$ & Yang [8] \\
\hline $\begin{array}{l}\text { Half velocity constant for } \\
\text { carbon dioxide }\end{array}$ & $K_{C}$ & 0.044 & $g C O_{2 D} m^{-3}$ & Yang [8] \\
\hline $\begin{array}{l}\text { Half velocity constant for } \\
\text { substrate }\end{array}$ & $K_{S}$ & 150 & BOD $m^{-3}$ & Yang [8] \\
\hline $\begin{array}{l}\text { Half velocity constant for } \\
\text { ammonia }\end{array}$ & $K_{N A}$ & 0.014 & $\mathrm{~g} \mathrm{~N} m^{-3}$ & Yang [8] \\
\hline $\begin{array}{l}\text { Half velocity constant for } \\
\text { oxygen }\end{array}$ & $K_{O_{2}}$ & 0.256 & $\mathrm{~g} C O_{2 D} m^{-3}$ & Yang [8] \\
\hline Partial pressure of oxygen & $P_{O_{2}}$ & 0.21 & atm & Yang [8] \\
\hline $\begin{array}{l}\text { Partial pressure of carbon } \\
\text { dioxide }\end{array}$ & $\mathrm{P}_{\mathrm{CO}_{2}}$ & 0.00032 & atm & Yang [8] \\
\hline Extinction coefficient & $K_{e 1}$ & 0.32 & $\mathrm{~m}^{-1}$ & Yang [8] \\
\hline Extinction coefficient & $K_{e 2}$ & 0.03 & $\mathrm{~m}^{-1}\left(\mathrm{~g} / \mathrm{m}^{3}\right)^{-1}$ & Yang [8] \\
\hline Saturation light intensity & $I_{S}$ & 14.63 & $\mathrm{M} / \mathrm{m}^{2} /$ day & Yang [8] \\
\hline Density of liquid & $\rho_{L}$ & $1 \mathrm{e} 3$ & $\mathrm{~kg} / \mathrm{m}^{3}$ & Yang [8] \\
\hline $\begin{array}{l}\text { Liquid viscosity of pure } \\
\text { water }\end{array}$ & $\mu_{L}$ & $9.07 \mathrm{e}-4$ & pa s & \\
\hline $\begin{array}{c}\text { Mass transfer coefficient } \\
\text { of } \mathrm{O}_{2}\end{array}$ & $\mathrm{k}_{\mathrm{lg}, \mathrm{O} 2}$ & 24 & day $^{-1}$ & Bai et al. [11] \\
\hline
\end{tabular}


Table 2

572

\begin{tabular}{ccccc}
\hline Item & $\begin{array}{c}\text { Parameter } \\
\text { description }\end{array}$ & Symbol & Nominal value & Unit \\
\hline \multirow{2}{*}{ pond } & $\begin{array}{c}\text { Pond depth } \\
\text { Hydraulic } \\
\text { retention time }\end{array}$ & 7 & $0.1-0.4$ & \\
\cline { 2 - 5 } & $\begin{array}{c}\text { Temperature } \\
\text { Maximum light } \\
\text { intensity }\end{array}$ & $I_{0}$ & 20 & day \\
\cline { 2 - 5 } & $\begin{array}{c}\text { Saturation light } \\
\text { intensity }\end{array}$ & $I S$ & 77.8 & $\mathrm{MJ} /\left(\mathrm{m}^{2}\right.$ day $)$ \\
& & 14.63 & $\mathrm{MJ} /\left(\mathrm{m}^{2}\right.$ day $)$ \\
\end{tabular}




\begin{tabular}{|c|c|c|c|c|}
\hline & $\begin{array}{l}\text { Number of } \\
\text { CSTR }\end{array}$ & - & 20 & - \\
\hline & $\begin{array}{l}\text { Photo-period (in } \\
\text { a 24-h day) }\end{array}$ & - & (5.00: 19.00) & hrs \\
\hline & Dilution rate & $R_{T}$ & $0.1-0.4$ & day $^{\wedge}-1$ \\
\hline \multirow{9}{*}{$\begin{array}{l}\text { Influent waste } \\
\text { water }\end{array}$} & $\begin{array}{l}\text { Influent waste } \\
\text { water flow rate }\end{array}$ & $\mathrm{F}$ & 50 & $\mathrm{~m}^{3} /$ day \\
\hline & $\begin{array}{l}\text { Biological } \\
\text { Oxygen } \\
\text { Demand }\end{array}$ & BOD & $0-50$ & $\mathrm{~g} / \mathrm{m}^{3}$ \\
\hline & $\begin{array}{l}\text { Total Inorganic } \\
\text { Carbon }\end{array}$ & $C_{T}$ & 102 & $\mathrm{~g} / \mathrm{m}^{3}$ \\
\hline & $\begin{array}{c}\text { Total } \\
\text { ammonium } \\
\text { Nitrogen }\end{array}$ & $N_{T}$ & 90 & $\mathrm{~g} / \mathrm{m}^{3}$ \\
\hline & $\begin{array}{l}\text { Influent oxygen } \\
\text { concentration }\end{array}$ & $M_{O X G}$ & 4 & $\mathrm{~g} / \mathrm{m}^{3}$ \\
\hline & $\begin{array}{l}\text { Total substrate } \\
\text { concentration }\end{array}$ & $\mathrm{S}$ & 300 & $\mathrm{~g} / \mathrm{m}^{3}$ \\
\hline & Temperature & $\mathrm{T}$ & 20 & ${ }^{\circ} \mathrm{C}$ \\
\hline & $\begin{array}{c}\text { Total algae } \\
\text { concentration }\end{array}$ & $X_{a}$ & 383 & $\mathrm{~g} / \mathrm{m}^{3}$ \\
\hline & $\begin{array}{l}\text { Total bacteria } \\
\text { concentration }\end{array}$ & $X_{b}$ & 0.005 & $\mathrm{~g} / \mathrm{m}^{3}$ \\
\hline \multirow{4}{*}{ Supplied gas } & $\begin{array}{c}\text { Volumetric flow } \\
\text { rate }\end{array}$ & $Q_{O}$ & 240 & $\mathrm{~m}^{3} /$ day \\
\hline & Pressure & & $0.11 \mathrm{e} 06$ & pa \\
\hline & Temperature & $\mathrm{T}$ & 20 & ${ }^{\circ} \mathrm{C}$ \\
\hline & $\begin{array}{l}\mathrm{CO}_{2} \text { molar } \\
\text { fraction }\end{array}$ & & 11 & $\begin{array}{c}\text { mass fraction } \\
(\%)\end{array}$ \\
\hline
\end{tabular}


575

576

577 